\title{
AN R PLASMID OF BROAD HOST-RANGE, CODING FOR RESISTANCE TO NINE ANTIMICROBIAL AGENTS ENDEMIC IN GRAM-NEGATIVE NOSOCOMIAL ISOLATES
}

\author{
S. Tantulavanich*, Vera M. Olexy*, T. R. Prasad*, \\ T. J. Bird* $\dagger$, Camille Talanda-Fath $\ddagger$, \\ H. G. GRIEBlE* $\S$ and S. K. Farrand* $\ddagger$ \\ *Infectious Disease Laboratory and $\uparrow$ Clinical Microbiology Laboratory, Hines Veteran \\ Administration Hospital, Hines, Illinois 60141, USA $\ddagger$ Department of Microbiology and \\ $\S$ Department of Medicine, Stritch School of Medicine, Loyola University of Chicago, \\ Maywood, Illinois 60153, USA
}

\section{Plates XX-XXIII}

Summary. Of 3952 clinical isolates of Enterobacteriaceae, 246 exhibited resistance to at least carbenicillin, gentamicin and tobramycin. All these isolates, representing eight genera, were resistant to at least nine antimicrobial agents in common, including the three key antibiotics and streptomycin, kanamycin, sisomycin, ampicillin, cephalothin and sulphonamide. The strains could be subdivided into seven groups depending upon additional resistance traits and some were resistant to as many as 15 antibiotics. When mated with a standard strain of Escherichia coli, $85 \%$ of 123 randomly selected donors transferred resistance to at least the nine core antibiotics. Some donors occasionally transferred resistance to two additional antibiotics, neomycin and tetracycline, while one Citrobacter freundi donor always transferred linked resistance to all 11 drugs. Although many donors were found to harbour more than one species of plasmid DNA, all except a strain of $C$. freundi contained at least a plasmid of mol. wt $89 \times 10^{6}$. Analysis of $E$. coli transconjugants showed this plasmid to be responsible for transferable resistance to the nine core antibiotics. Restriction-endonuclease analysis indicates that the $89 \times 10^{6}$ plasmids originating from different isolates were essentially identical with each other. These results show that a particular $\mathrm{R}$ plasmid has established itself among the Enterobacteriaceae at Hines VA Hospital. This $\mathrm{R}$ plasmid appears to be the predominant genetic element responsible for linked resistance to carbenicillin, gentamicin and tobramycin among these hospitalassociated bacteria.

Received 17 Oct. 1980; revised version accepted 2 Mar. 1981.

In memoriam Hans G. Grieble, Chief of Infectious Disease, Hines V.A. Hospital, 21 February 1928-30 April 1980.

Requests for reprints should be sent to Dr S. K. Farrand, Department of Microbiology, Stritch School of Medicine, 2160 South First Avenue, Maywood, Illinois 60153, USA. 


\section{INTRODUCTION}

The introduction of new antibiotics has invariably resulted in the emergence of resistant strains of bacteria, in particular gram-negative opportunists associated with nosocomial infections (Farrar, 1979). Resistance in these organisms may be due to chromosomal mutation, but more commonly it appears to result from the acquisition of $\mathrm{R}$ plasmids bearing genetic resistance determinants (Falkow, 1975). The emergence and dissemination of R-plasmid-mediated resistance to new antibiotics among populations of hospital-associated bacteria can be due to any one or more of three general phenomena. Mutations may occur in genes carried by existing $\mathrm{R}$ plasmids which give rise to inactivating enzymes or other factors now operative on the new antibiotic. Alternatively, novel $\mathrm{R}$ plasmids, bearing the new resistance determinants, may be introduced into the bacterial population. In this case, the new R plasmid may either displace or co-exist with previously established genetic elements. Finally, such new R plasmids may be introduced and then eliminated but in the process donate, either by conventional recombinational mechanisms or by transposition, new resistance determinants to established endogenous plasmids. Evidence exists for each of these cases and for situations in which more than one mechanism appear to have occurred (Ingram, Richmond and Sykes, 1973; Jobanputra and Datta, 1974; Korfhagen, Loper and Ferrel, 1975; Mawer and Greenwood, 1977; Rennie and Duncan, 1977; Curie et al., 1978; Elwell, Inamine and Minshew, 1978; Datta et al., 1979; Gerding et al., 1979; Rubens, McNeill and Farrar, 1979; Sadowski et al., 1978, 1979; Datta et al., 1980).

We have, for the past three years, been following the emergence of resistance to the newer penicillin and aminoglycoside antibiotics, carbenicillin . $(\mathrm{Cb})$, gentamicin $(\mathrm{Gm})$ and tobramycin $(\mathrm{Tm})$ among gram-negative clinical isolates at Hines Veterans Administration Hospital (HVAH). In 1977, we obtained an isolate of Proteus mirabilis resistant to 13 antibiotics including the three indicated above, and in 1978 we reported a series of isolates of Serratia marcescens exhibiting similar antibiograms (Olexy et al., 1978, 1979). In genetic studies, these strains were shown to transfer resistance to as many as 11 antibiotics including $\mathrm{Cb}, \mathrm{Gm}$ and Tm (Olexy et al., 1979). Physical studies showed that a plasmid of mol. wt $89 \times 10^{6}$ was involved (Olexy et al., 1978).

These results prompted us to examine the prevalence of resistance to $\mathrm{Cb}$, $\mathrm{Gm}$ and $\mathrm{Tm}$ among all clinical gram-negative isolates. We approached this problem by screening for antibiotic resistance all clinical isolates of Enterobacteriaceae and selecting for more detailed analysis those resistant to at least $\mathrm{Cb}$, $\mathrm{Gm}$ and Tm. In this report we show that at HVAH the emergence of resistance to these three antibiotics among Enterobacteriaceae was due in most instances to the introduction and establishment of a single $\mathrm{R}$ plasmid of extended host-range (Prasad et al., 1978).

MATERIALS AND METHODS

Bacterial strains. Standard strains of Escherichia coli and Pseudomonas aeruginosa used in 
the genetic crosses and their propagation and storage have been described (Olexy et al., 1979). Clinical isolates resistant to at least $\mathrm{Cb}, \mathrm{Gm}$ and $\mathrm{Tm}$ were obtained from the Clinical Microbiology Laboratory, HVAH. Isolates were identified and speciated in the Clinical Microbiology Laboratory, HVAH.

Culture media. Minimal media, nutrient agar and $\mathrm{L}$ broth were prepared as previously described (Olexy et al., 1979).

Determination of resistance patterns. Clinical isolates and genetic progeny were tested for antibiotic resistance by the disc-diffusion technique of Bauer et al. (1966) as described by Olexy et al. (1979). The assays were performed on Mueller-Hinton agar and resistant and susceptible strains were always included as controls.

Mating techniques and progeny analysis. Bacterial matings were performed on nitrocellulose filters to maximise cell-cell contact essentially as described by Olexy et al. (1979). After matings, selections were made for only one antibiotic resistance conferred by the donor, and acquisition of unselected resistance markers was determined by the method of Bauer et al. (1966) as described above.

Plasmid isolation and analysis. DNA was partially purified from bacterial lysates by a technique similar to that described by Casse et al. (1979). These samples were analysed for plasmid content by agarose-gel electrophoresis as described by Hamada, Luckey and Farrand (1979). A mixture of five plasmids of known molecular weight was used to determine the molecular weights of plasmid species isolated from clinical isolates (Meyers et al., 1976).

Restriction-endonuclease analysis. Plasmid DNA, purified by two rounds of centrifugation in $\mathrm{CsCl}$-ethidium bromide (EtBr) gradients (Currier and Nester, 1976), were cleaved with the site-specific restriction endonuclease, HincII, in conditions described by the supplier (New England Biolabs, 283 Cabot Street, Beverly, Massachusetts, 01915, USA), and cleavage products were separated and analysed by agarose-gel electrophoresis as previously described (Farrand, Kado and Ireland, 1981).

\section{RESULTS}

\section{Analysis of clinical isolates}

During a 10-month period in 1978, 246 of $3952(6 \cdot 2 \%)$ single clinical isolates representing eight genera of Enterobacteriaceae were found to show combined resistance to at least $\mathrm{Cb}, \mathrm{Gm}$ and $\mathrm{Tm}$ (table I). Although these mutliply resistant isolates comprised only $6 \cdot 2 \%$ of the total tested, as many as

TABLE I

Resistance of Enterobacteriaceae to carbenicillin, gentamicin and tobramycin

\begin{tabular}{l|ccc}
\hline \multicolumn{1}{c|}{ Genus } & $\begin{array}{c}\text { Number of } \\
\text { strains } \\
\text { tested }\end{array}$ & $\begin{array}{c}\text { Number (and percentage) } \\
\text { of strains resistant } \\
\text { to Cb, Gm and Tm }\end{array}$ \\
\hline Escherichia & 1031 & $34(3 \cdot 3)$ \\
Citrobacter & 177 & $10(5 \cdot 6)$ \\
Klebsiella & 660 & $38(5 \cdot 8)$ \\
Enterobacter & 444 & $26(5 \cdot 9)$ \\
Serratia & 181 & $48(26 \cdot 5)$ \\
Proteus & 932 & $27(2 \cdot 9)$ \\
Providencia & 385 & $60(15 \cdot 6)$ \\
Morganella & 142 & 3 & $(2 \cdot 1)$ \\
\multicolumn{1}{c}{ All } & 3952 & $246(6 \cdot 2)$ \\
\hline
\end{tabular}

$\mathrm{Cb}=$ carbenicillin, $\mathrm{Gm}=$ gentamicin, $\mathrm{Tm}=$ tobramycin . 
TABLE II

Additional resistance characteristics of multiply resistant clinical isolates

\begin{tabular}{|c|c|c|}
\hline Group & Representative strain & Resistance pattern* \\
\hline I & $\begin{array}{l}\text { Enterobacter aerogenes } \\
\text { Klebsiella pneumoniae } \\
\text { Citrobacter diversus }\end{array}$ & $\begin{array}{l}\text { Tp } \\
\text { Tp } \\
\text { Tp }\end{array}$ \\
\hline II & Serratia marcescens & $\mathrm{Tp} \mathrm{Pb}$ \\
\hline III & $\begin{array}{l}\text { En. agglomorans } \\
\text { Escherichia coli }\end{array}$ & $\begin{array}{l}\mathrm{Nm} \mathrm{Tc} \\
\mathrm{Nm} \mathrm{Tc}\end{array}$ \\
\hline IV & $\begin{array}{l}\text { En. cloacae } \\
\text { C. freundi }\end{array}$ & $\begin{array}{l}\text { Nm Tc Tp } \\
\text { Nm Tc Tp }\end{array}$ \\
\hline V & $\begin{array}{l}\text { S. marcescens } \\
\text { Proteus mirabilis }\end{array}$ & $\begin{array}{l}\mathrm{Nm} T c \mathrm{Tp} \mathrm{Pb} \\
\mathrm{Nm} \mathrm{Tc} \mathrm{Tp} \mathrm{Pb}\end{array}$ \\
\hline VI & $\begin{array}{l}\text { Providencia stuarti }\left(\mathrm{u}^{-}\right) \\
\text {Pr. stuarti }\left(\mathrm{u}^{+}\right)\end{array}$ & $\begin{array}{l}\mathrm{Nm} T c \mathrm{Tp} \mathrm{Pb} \mathrm{Na} \\
\mathrm{Nm} \mathrm{Tc} \mathrm{Tp} \mathrm{Pb} \mathrm{Na} \mathrm{Cm}\end{array}$ \\
\hline VII & P. rettgeri & $\mathrm{Nm} \mathrm{Tc} \mathrm{Tp} \mathrm{Pb} \mathrm{Na} \mathrm{Cm}$ \\
\hline
\end{tabular}

$\mathrm{Tp}=$ trimethoprim, $\mathrm{Pb}=$ polymyxin $\mathrm{B}, \mathrm{Nm}=$ neomycin, $\mathrm{Tc}=$ tetracycline, $\mathrm{Na}=$ nalidixic acid, $\mathrm{Cm}=$ chloramphenicol. $\left(\mathrm{u}^{-}\right)=$incapable and $\left(\mathrm{u}^{+}\right)=$capable of splitting urea.

* All strains were resistant to the nine core antibacterial agents: ampicillin, carbenicillin, cephalothin, streptomycin, kanamycin, gentamicin, tobramycin, sisomycin and sulphonamide.

$26 \%$ of the isolates for certain genera showed resistance to the key antibiotics.

All of these 246 strains, selected for study only because they were resistant to $\mathrm{Cb}, \mathrm{Gm}$ and $\mathrm{Tm}$, showed common resistance to at least six additional antimicrobial agents including ampicillin (Ap), cephalothin (Ce), streptomycin $(\mathrm{Sm})$, kanamycin $(\mathrm{Km})$, sisomycin $(\mathrm{Si})$ and sulphonamide $(\mathrm{Su})$. The isolates could be divided into seven patterns based on the addition of other resistance traits to this core of nine antibiotics (table II). In total, 80 of the $246(33 \%)$ manifested only the core pattern while $166(67 \%)$ were resistant to as many as six additional antibiotics. Some of the eight genera represented exhibited predominantly the core pattern only, while others showed resistance to

TABLE III

Distribution of multiply resistant Enterobacteriaceae to core and core +other patterns

\begin{tabular}{|c|c|c|c|}
\hline \multirow[b]{2}{*}{ Genus } & \multirow{2}{*}{$\begin{array}{c}\text { Number } \\
\text { of strains } \\
\text { tested }\end{array}$} & \multicolumn{2}{|c|}{$\begin{array}{l}\text { Number (and percentage) of } \\
\text { strains resistant to }\end{array}$} \\
\hline & & core antibodies* & core + other antibiotics \\
\hline $\begin{array}{l}\text { Escherichia } \\
\text { Citrobacter } \\
\text { Klebsiella } \\
\text { Enterobacter } \\
\text { Serratia } \\
\text { Providencia } \\
\text { Proteus } \\
\text { Morganella }\end{array}$ & $\begin{array}{r}34 \\
10 \\
38 \\
26 \\
48 \\
60 \\
27 \\
3\end{array}$ & $\begin{array}{rr}23 & (68 \%) \\
4 & (40 \%) \\
31 & (82 \%) \\
11 & (42 \%) \\
5 & (10 \%) \\
3 & (5 \%) \\
0 & (0 \%) \\
3 & (100 \%)\end{array}$ & $\begin{array}{rr}11 & (32 \%) \\
6 & (60 \%) \\
7 & (18 \%) \\
15 & (58 \%) \\
43 & (90 \%) \\
57 & (95 \%) \\
27 & (100 \%) \\
0 & (0 \%)\end{array}$ \\
\hline All & 246 & $80(33 \%)$ & $166(67 \%)$ \\
\hline
\end{tabular}

* See footnote to table II. 
additional antibiotics (table III). All were sensitive to amikacin and netilmicin.

\section{Resistance transfer}

To determine whether resistance to the three key antibiotics was mediated by conjugative $\mathrm{R}$ plasmids, $123(50 \%)$ randomly selected clinical isolates representing each of the eight genera were independently mated with $E$. coli strain C1200-1, a plasmidless, well-marked, rifampicin-resistant, restrictionless recipient (Olexy et al., 1979). Of the donor strains, $105(85 \%)$ were observed to transfer gentamicin resistance. Although the number of strains transferring resistance approached $100 \%$ for most genera, only five of seven ( $71 \%$ ) of Citrobacter donors and 14 of $29(48 \%)$ of Providencia donors could be shown to be fertile (table IV). Similar results were obtained when carbenicillin was used as the selective antibiotic.

TABLE IV

Transfer characteristics of multiply resistant clinical isolates*

\begin{tabular}{|c|c|c|c|c|}
\hline \multirow[b]{2}{*}{$\begin{array}{l}\text { Donor } \\
\text { genus }\end{array}$} & \multirow{2}{*}{$\begin{array}{l}\text { Number } \\
\text { of strains } \\
\text { tested }\end{array}$} & \multicolumn{2}{|c|}{$\begin{array}{l}\text { Number (and percentage) } \\
\text { of strains }\end{array}$} & \multirow[b]{2}{*}{$\begin{array}{l}\text { Frequency of } \\
\text { transfer } \ddagger\end{array}$} \\
\hline & & transferring $\dagger$ & $\begin{array}{l}\text { transferring } \\
\text { core pattern }\end{array}$ & \\
\hline $\begin{array}{l}\text { Escherichia } \\
\text { Citrobacter } \\
\text { Klebsiella } \\
\text { Enterobacter } \\
\text { Serratia } \\
\text { Providencia } \\
\text { Proteus } \\
\text { Morganella }\end{array}$ & $\begin{array}{r}14 \\
7 \\
15 \\
15 \\
27 \\
29 \\
13 \\
3\end{array}$ & $\begin{array}{r}13(93 \%) \\
5(71 \%) \\
15(100 \%) \\
15(100 \%) \\
27(100 \%) \\
14(48 \%) \\
13(100 \%) \\
3(100 \%)\end{array}$ & $\begin{array}{r}13(100 \%) \\
5(100 \%) \\
15(100 \%) \\
15(100 \%) \\
27(100 \%) \\
14(100 \%) \\
13(100 \%) \\
3(100 \%)\end{array}$ & $\begin{array}{l}10^{-1}-<10^{-9} \\
10^{-2}-<10^{-9} \\
10^{-1}-10^{-5} \\
10^{-1}-10^{-4} \\
10^{-2}-10^{-6} \\
10^{-2}-<10^{-9} \\
10^{-4}-10^{-6} \\
10^{-4}-10^{-6}\end{array}$ \\
\hline
\end{tabular}

* Escherichia coli strain C1200-1 (Olexy et al., 1979) was used as the recipient.

$\dagger$ Transconjugants were selected on nutrient agar supplemented with rifampicin $(100 \mu \mathrm{g} / \mathrm{ml})$ and gentamicin $(50 \mu \mathrm{g} / \mathrm{ml})$.

$\ddagger$ Expressed as the number of transconjugants recovered per ml divided by the input titre of the donor.

When screened for the acquisition of unselected resistance markers, the vast majority of transconjugants coinherited resistance to at least the nine antibiotics comprising the core pattern. A few transconjugants showing resistance to neomycin $(\mathrm{Nm})$ and tetracycline $(\mathrm{Tc})$ in addition to the core pattern were isolated from matings with donors of groups III-VII (table III). However, even with donors resistant to as many as 15 antibiotics, consistent resistance transfer was observed only for the nine comprising the core pattern. One $C$. freundi donor, strain 1587 , proved the exception, invariably transferring resistance to 11 antibiotics including the core pattern. $\mathrm{Nm}$ and Tc. Unselected transfer of resistance to trimethoprim, polymixin B, nalidixic acid, or chloramphenicol was never observed with any donor. 


\section{Plasmid analysis}

The genetic evidence presented above suggested that the clinical isolates harbour at least one conjugative $\mathrm{R}$ plasmid coding for resistance to as many as nine antibiotics. To test this directly, samples of partially purified DNA from representative donors of each genus were subjected to agarose-gel electrophoresis. As shown in fig. 1, all strains tested harboured at least one plasmid; in some, such as Enterobacter agglomorans strain 1051, there were as many as four. With one exception, all isolates showed the presence of a plasmid with an estimated mol. wt of $89 \times 10^{6}$. The strain of $C$. freundi, which consistently transferred resistance to 11 antibiotics, showed a single large plasmid with a mol. wt estimated at $62 \times 10^{6}$ (fig. 1, lane G). While some strains resistant to and transferring only the core pattern harboured a single plasmid, others contained more than one extrachromosomal element. In contrast, those resistant to additional antibiotics and occasionally transferring resistance to $\mathrm{Nm}$ and Tc, all contained an additional $57 \times 10^{6}$ plasmid, (fig. 1, lanes $\mathrm{A}, \mathrm{C}$ and E).

To associate a plasmid conclusively with the transferable resistance phenotypes, partially purified DNA samples from $E$. coli transconjugants were analysed. Transconjugants representing progeny from crosses with several different donors of each genus were assayed. When such transconjugants resistant only to the nine core antibiotics were analysed, all were observed to have acquired an $89 \times 10^{6}$ plasmid (fig. 2). In contrast, those rare transconjugants acquiring resistance to $\mathrm{Nm}$ and Tc were found to harbour an 89 and a $57 \times 10^{6}$ plasmid identical to those seen in the donors (fig. 3, compare lanes A with $B$ and $C$ with $D$ ). As described above, all transconjugants derived from matings with the $C$. freundi donor acquired resistance to $\mathrm{Nm}$ and $\mathrm{Tc}$ in addition to the nine core antibiotics. These progeny were found to have inherited a $62 \times 10^{6}$ plasmid apparently identical in mass to the one large plasmid present in the donor (fig. 3, compare lanes $\mathrm{E}$ and F).

\section{Restriction-endonuclease analysis}

The data presented above suggested that the $89 \times 10^{6}$ plasmid common to the vast majority of the multiply resistant clinical isolates was an $\mathrm{R}$ plasmid coding for resistance to nine antibiotics including $\mathrm{Cb}, \mathrm{Gm}$ and $\mathrm{Tm}$. To confirm that these large elements from the various isolates were indeed the same plasmid, restriction-endonuclease digest fingerprints of representative DNA samples isolated and purified from $E$. coli transconjugants were compared. Such nucleolytic enzymes, which are site specific and therefore capable of generating unique digest profiles, have been used to determine the relatedness between other plasmids purified from clinical isolates (Rubens $e t$ al., 1979, Sadowski et al., 1978, 1979). As seen in fig. 4A, the plasmids deriving from six different genera showed essentially indistinguishable cleavage patterns. That of P. rettgeri (lane 3 ) differs from the others only in the absence of the highest molecular-weight fragment and the appearance of three new 


\section{AN ENDEMIC R PLASMID}

\section{$\begin{array}{lllllll}\text { A } & \text { B } & \text { C } & \text { D } & \text { E } & F & G\end{array}$}

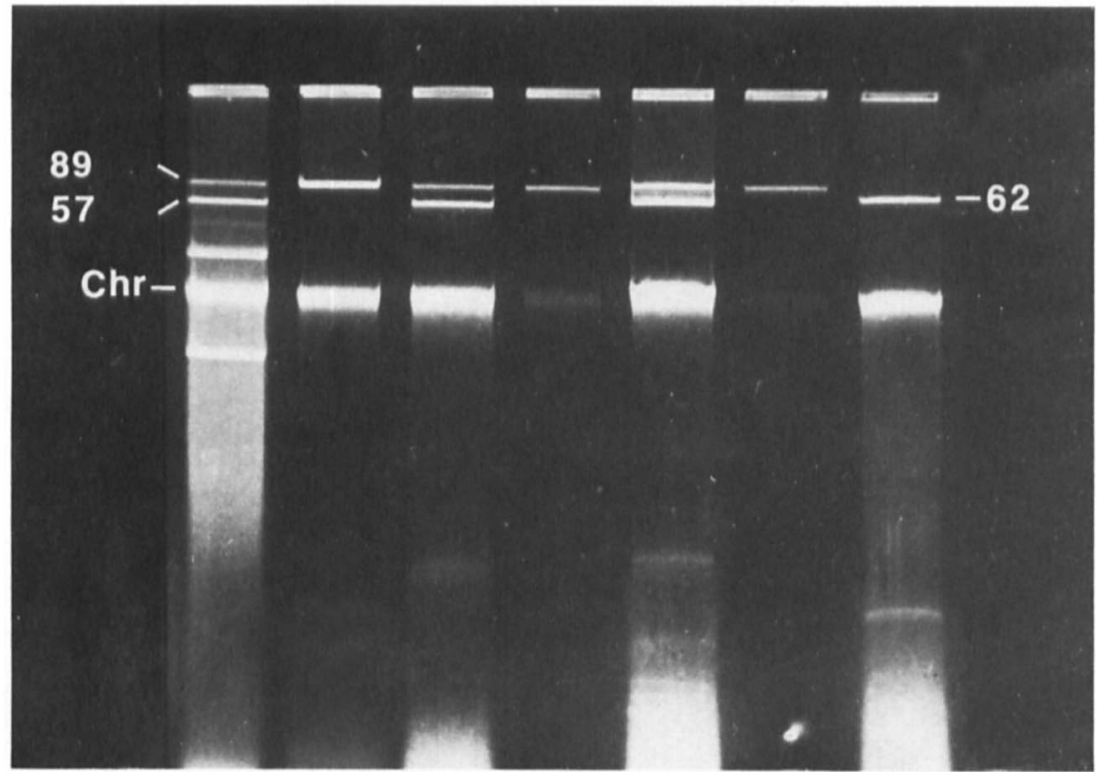

FIG. 1.-Agarose-gel electrophoresis of partially purified plasmid DNA from multiply resistant clinical isolates: A, Enterobacter agglomorans strain 1051; B, Proteus rettgeri strain 2035; C, Serratia marcescens strain 612; D, Klebsiella pneumoniae strain 325; E, Escherichia coli strain 2052; F, Citrobacter diversus strain $953 ; \mathrm{G}$, C. freundi strain 1587 . Each sharp bright band corresponds to a plasmid of unique mol. wt $\left(10^{6}\right)$ as indicated in the margins. The less defined bands, present in variable amounts in each sample, represent linear fragments of chromosomal DNA (Chr). 


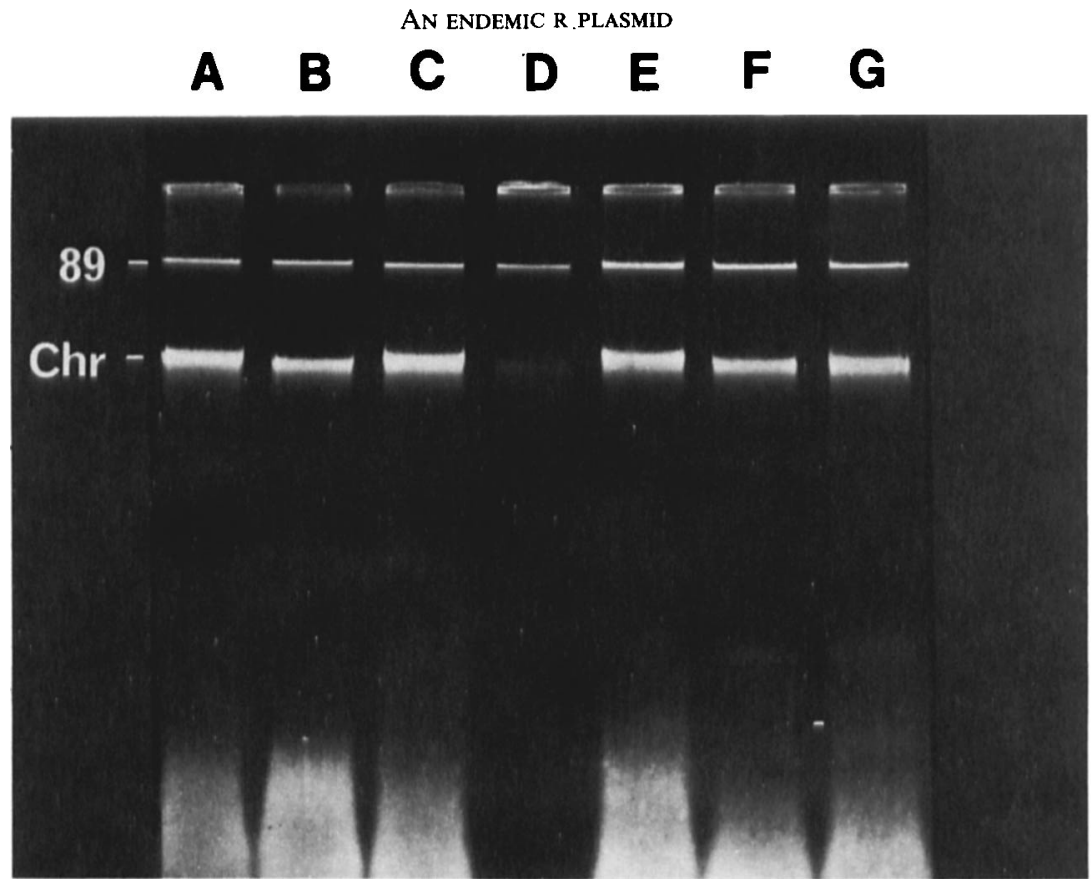

FIG. 2.-Agarose-gel electrophroesis of plasmid DNA from E. coli strain C1200-1 transconjugants showing resistance to only the nine core antibiotics and derived from matings with: A, En. agglomorans strain 1051; B, P. rettgeri strain 2035; C, En. cloacae strain 2119; D. K. pneumoniae 325; E. E. coli strain 2052; F. C. diversus strain 953, G. Pr. stuarti strain 1285. See legend to fig. 1 for explanation of band markings. 


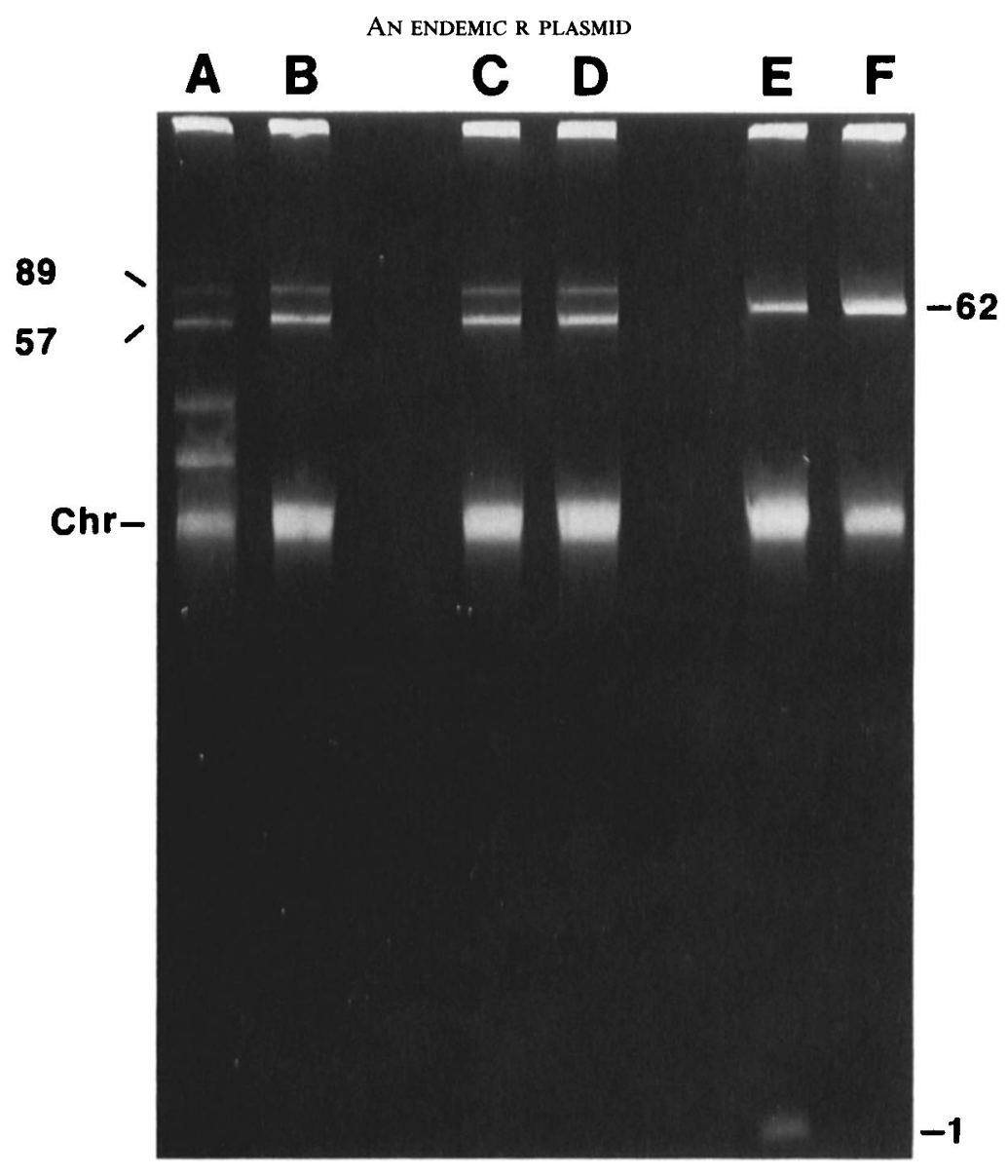

FIG. 3.-Agarose-gel electrophoresis of plasmid DNA from clinical isolates transferring resistance to neomycin and tetracycline in addition to the nine core antibiotics and their $E$. coli transconjugants: A, En. agglomorans strain 1051; B, E. coli strain C1200-1 (En. agglomorans strain 1051) $\mathrm{Nm}^{\mathrm{R}} \mathrm{Tc}^{\mathrm{R}} ; \mathrm{C}$, E. coli strain 2052; D, E. coli strain C1200-1 (E. coli strain 2052) $\mathrm{Nm}^{\mathrm{R}} \mathrm{Tc}^{\mathrm{R}} ; \mathrm{E}$, C. freundi strain $1587 ; \mathrm{F}$, E. coli strain C1200-1 (C. freundi strain 1587). See legend to fig. 1 for explanation of band markings. 


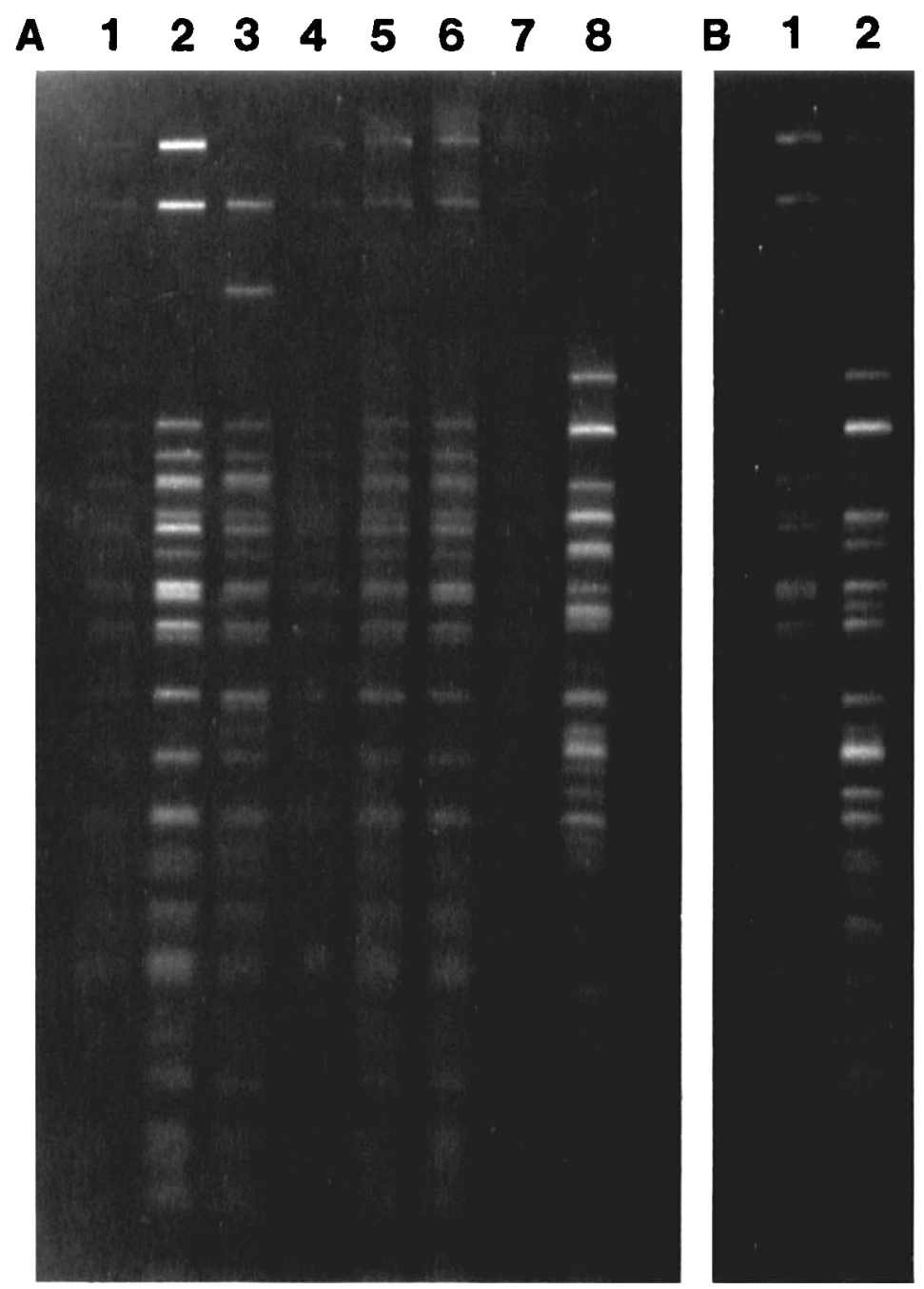

FIG. 4.-Restriction-endonuclease analysis of R plasmid DNA. Purified plasmid DNA was subjected to digestion with HincII and the resultant DNA fragments analysed by agarose-gel electrophoresis. The lanes contain plasmid DNA isolated from (panel A) E. coli strain C1100-1 transconjugants derived from matings with: 1, P. mirabilis strain $2138 ; 2$, Pr. stuarti strain $1285 ; 3$, P. rettgeri strain $2035 ; 4$, En. agglomorans strain 1051; 5, C. diversus strain 953; 6, K. pneumoniae strain 325; 7, E. coli strain 2052; 8, C. freundi strain 1587 and (panel B) 1, C1200-1 (En. agglomorans strain 1051); 2, C1200-1 (En. agglomorans strain 1051$) \mathrm{Nm}^{\mathrm{R}} \mathrm{Tc}^{\mathrm{R}}$. 
smaller fragments. Evidently fragment 1 of this plasmic acquired two new HincII sites. The $62 \times 10^{6}$ plasmid from $C$. freundi (lane 8) represents something of an enigma. This plasmid, which codes for resistance to the nine core antibiotics, $\mathrm{Nm}$ and $\mathrm{Tc}$ has some HincII fragments that are unique and others similar to those of the $89 \times 10^{6}$ species. Digestion of plasmid DNA isolated from transconjugants harbouring the 89 and the $57 \times 10^{6}$ plasmids showed the presence of all of the $89 \times 10^{6}$ plasmid fragments and additional species presumably attributable to the $57 \times 10^{6}$ element (fig. 4B, lane 2). Note that the strains analysed in fig. 4B were both derived from a mating with En. agglomorans strain 1051. Lane 1 shows the digest pattern of plasmid DNA isolated from a $\mathrm{Nm}^{\mathrm{S}} \mathrm{Tc}^{5}$ E. coli transconjugant harbouring the $89 \times 10^{6}$ plasmid only (see fig. 2 lane A). Its digestion pattern is identical to that of other isolates of the $89 \times 10^{6}$ plasmid (compare fig. 4B, lane 1 with fig. 4A, lanes 1, 2 and 4-7). Lane 2 of fig. $4 \mathrm{~B}$ shows a digest of plasmid DNA from a $\mathrm{Nm}^{\mathrm{R}} \mathrm{Tc}^{\mathrm{R}}$ E. coli transconjugant harbouring the 89 and the $57 \times 10^{6}$ plasmids (see fig. 3, lane B). This digestion pattern is much more complex, but contains, as a subset, all the fragments present in the $89 \times 10^{6}$ element.

\section{DisCUSSION}

The physical and genetic analyses presented above indicate that a single $\mathrm{R}$ plasmid with a mol. wt estimated at $89 \times 10^{6}$ is responsible for resistance to $\mathrm{Cb}, \mathrm{Gm}, \mathrm{Tm}$ and six other antibiotics among gram-negative clinical isolates at HVAH. Similar results, showing that a single plasmid was responsible for resistance to a series of antibiotics, have been reported (Ingram et al., 1973; Elwell et al., 1978; Sadowski et al., 1978, 1979). However, in most of these studies only a few isolates, or isolates from one particular outbreak or hospital section or showing a single homogeneous resistance pattern were studied.

In the present study, the clinical isolates were chosen solely on the basis of resistance to the three key antibiotics. However, all were also resistant to at least six other antibiotics, to complete what we call the core pattern. These 246 resistant isolates could then be divided into seven groups based on additional resistance characteristics (table II). Although some of the isolates were resistant to as many as 15 antibiotics, the vast majority tested transferred resistance only to $\mathrm{Ap}, \mathrm{Cb}, \mathrm{Ce}, \mathrm{Sm}, \mathrm{Km}, \mathrm{Gm}, \mathrm{Tm}, \mathrm{Si}$ and $\mathrm{Su}$, the nine resistance traits comprising the core pattern. Analysis of the donors and their E. coli transconjugants (figs. 1, 2 and 3) clearly showed this transferable resistance pattern to be associated with conjugative plasmids, all, with one exception, having a mol. wt estimated at $89 \times 10^{6}$. Restriction-endonuclease analysis (figs. 4A and 4B) showed these $89 \times 10^{6}$ plasmids to be virtually identical regardless of the original source. Thus several criteria including resistance pattern, genetic transferability and molecular characteristics clearly show that a single plasmid has established itself within the gram-negative hospital flora. Furthermore, given the conditions by which clinical isolates were chosen for this study, this plasmid is apparently the primary agent responsible for linked 
resistance to $\mathrm{Cb}, \mathrm{Gm}$ and $\mathrm{Tm}$ among clinical isolates of the Enterobacteriaceae at $\mathrm{HVAH}$.

Some of the isolates occasionally transferred resistance to $\mathrm{Nm}$ and $\mathrm{Tc}$ in addition to the nine core antibiotics. Molecular analysis showed this transfer to be associated with a $57 \times 10^{6}$ plasmid present in the donor strains (figs. 3 and 4). Like the larger plasmid it has also established itself in a wide range of gram-negative species isolated at HVAH (fig. 1).

However, the expression of $\mathrm{Nm}$ and Tc resistance among our isolates did not always correlate with presence of the $57 \times 10^{6}$ plasmid. For example, the group-V S. marcescens isolates harboured this plasmid and occasionally transferred resistance to $\mathrm{Nm}$ and Tc. The group-V P. mirabilis isolate, on the other hand, showed an identical resistance phenotype but lacked the $57 \times 10^{6}$ species and never transferred resistance to $\mathrm{Nm}$ or Tc. Thus, as has been previously emphasised (Richmond, 1975), identical resistance patterns represent insufficient criteria to prove identity of plasmids.

Some evolution of the $89 \times 10^{6}$ plasmid appears to be occurring. Our first isolation of this plasmid was from a strain of $P$. mirabilis in 1977 (C. Talanda-Fath, 1980). This plasmid is virtually identical to its counterparts purified from clinical isolates representing other genera obtained in 1977 and 1978 (compare fig. 4, lane 1 with lanes 2 and 4-7). However, the $89 \times 10^{6}$ plasmid from P. rettgeri (fig. 4, lane 3) appears to have gained additional HincII sites without any noticeable alteration in size or detectable phenotype.

By contrast, the $\mathrm{R}$ plasmid from $C$. freundi may represent a substantial modification of the $89 \times 10^{6}$ species. This $62 \times 10^{6}$ element apparently codes for resistance to the nine core antibiotics along with $\mathrm{Nm}$ and Tc. Cleavage analysis (fig. 4, lane 8) showed this plasmid to have fragments in common with the $89 \times 10^{6}$ species. In the absence of firm evidence we can only speculate that this $\mathrm{R}$ plasmid arose by some set of recombinational events between the 89 and the $57 \times 10^{6}$ species. Finally, we have just isolated from a strain of Pr. stuarti a natural derivative of the $89 \times 10^{6}$ plasmid which appears to code for urease production. We are now analysing this latter plasmid as to its molecular characteristics.

It is clear that the $89 \times 10^{6}$ plasmid described in this work is endemic within the Enterobacteriaceae associated with nosocomial infections at Hines VAH. Furthermore, this R plasmid appears to be the primary vector for resistance to carbenicillin, gentamicin and tobramycin among those isolates. We are continuing to monitor the presence and evolution of this genetic element.

This work was supported in part by grant no. 3285 from the Central Veterans Administration and by BRSG grant no. RR05368 to Dr S. K. Farrand from the Stritch School of Medicine.

\section{REFERENCES}

Bauer, A. W., Kirby, W. M. M., Sherris, J. C., AND TurCK, M. 1966. Antibiotic susceptibility testing by a standardized single disc method. Am. J. clin. Path., 45, 493. 
CAsse, F., Boucher, C., Julliot, J. S., Michel, M. and Dénarié, J. 1979. Identification and characterization of large plasmids in Rhizobium meliloti using agarose gel electrophoresis. J. gen. Microbiol., 113, 229.

Curie, K., Speller, D. C. E., Simpson, R. A., Stephens, M. AND CoOKe, D. I. 1978. A hospital epidemic caused by a gentamicin-resistant Klebsiella aerogenes. J. Hyg., Camb., 80, 115.

CURRIER, T. C. AND NESTER, E. W. 1976. Isolation of covalently closed circular DNA of high molecular weight from bacteria. Analyt. Biochem., 76, 431.

Datta, N., Hughes, V. M., Nugent, M. E. and Richards, H. 1979. Plasmids and transposons and their stability and mutability in bacteria isolated during an outbreak of hospital infection. Plasmid, 2, 182.

Datta, N., Dacey, S., Hughes, V., Knight, S., Richards, H., Williams, G., Casewell, M. AND Shannon, K. P. 1980. Distribution of genes for trimethoprim and gentamicin resistance in bacteria and their plasmids in a general hospital. J. gen. Microbiol., 118, 495.

Elwell, L. P., Inamine, J. M. And Minshew, B. H. 1978. Common plasmid specifying tobramycin resistance found in two enteric bacteria isolated from burn patients. Antimicrob. Agents Chemother., 13, 312.

FALKOW, S. 1975. Infectious multiple drug resistance, Pion, London.

FARRAND, S. K., KaDO, C. I., AND IRELAND, C. R. 1981. Suppression of tumorigenicity by the Inc W R plasmid pSa in Agrobacterium tumefaciens. Molec. gen. Genet., 181, 44.

Farrar, W. E. 1979. Antibiotic resistance in intestinal bacteria. Clin. Gastroenterol, 8, 803.

Gerding, D. N., Buxton, A. E., Hughes, R. A., Cleary, P. P. Arbaczawski, J. and Stamm, W. E. 1979. Nosocomial multiply resistant Klebsiella pneumoniae: epidemiology of an outbreak of apparent index case origin. Antimicrob. Agents Chemother., 15, 608.

Hamada, S. E., LuCKeY, J. P. AND FarRand, S. K. 1979. R-plasmid-mediated chromosomal gene transfer in Agrobacterium tumefaciens. J. Bact., 139, 280.

INGRAM, L. C., RICHMOND, M. H. AND SYKeS, R. B. 1973. Molecular characterization of the R factors implicated in the carbenicillin resistance of a sequence of Pseudomonas aeruginosa strains isolated from burns. Antimicrob. Agents Chemother., 3, 279.

JobanputRa, R. S., AND DatTA, N. 1974. Trimethoprim R factors in enterobacteria from clinical specimens. J. med. Microbiol., 7, 169.

Korfhagen, T. R., Loper, J. C. AND Ferrel, J. A. 1975. Pseudomonas aeruginosa R factors determining gentamicin plus carbenicillin resistance from patients with urinary tract colonizations. Antimicrob. Agents Chemother., 7, 64.

MAWER, S. L., AND GREENWOOD, D. 1977. Aminoglycoside resistance emerging during therapy. Lancet, 1, 749.

Meyers, J. A., Sanchez, D., Elwell, L. P. and Falkow, S. 1976. Simple agarose gel electrophoretic method for the identification and characterization of plasmid deoxyribonucleic acid. J. Bact., 127, 1529.

Olexy, V., BiRD, T., GRIEble, H. AND FarRand, S. 1978. Characterization of R factors from Serratia marcescens transferable to Pseudomonas aeruginosa. Abstr. ann. Mtg. Am. Soc. Microbiol., 1, 123.

Olexy, V. M., Bird, T. J., Grieble, H. G. and Farrand, S. K. 1979. Hospital isolates of Serratia marcescens transferring ampicillin, carbenicillin, and gentamicin resistance to other gram-negative bacteria including Pseudonomas aeruginosa. Antimicrob. Agents Chemother., 15, 93.

Prasad, T., Olexy, V., Talanda-Fath, C., Grieble, H. and Farrand, S. 1978. Identity between R-factors coding for resistance to carbenicillin and gentamicin isolated from various species of Enterobacteriaceae. Abstr. ann. Mtg. Am. Soc. Microbiol., 1, 123.

ReNNIE, R. P. AND DunCAN, I. B. R. 1977. Emergence of gentamicin-resistant Klebsiella in a general hospital. Antimicrob. Agents Chemother., 11, 179.

RichMOND, M. H. 1975. R factors in man and his environment. In Microbiology 1974, edited by D. Schlessinger, American Society for Microbiology, Washington DC, pp. 27-35.

Rubens, C. E., NCNeill, W. F. AND Farrar, W. E. 1979. Evolution of multiple-antibioticresistance plasmids mediated by transposable plasmid deoxyribonucleic acid sequences. $J$. Bact., 140, 713. 
Sadowski, P. L., Peterson, B. C., Gerding, D. and Cleary, P. P. 1978a. Use of a restriction endonuclease to establish the persistence and epidemic spread of a single $\mathrm{R}$ plasmid in the hospital environment. In Microbiology 1978, edited by D. Schlessinger, American Society for Microbiology, Washington DC, pp. 270-272.

Sadowski, P. L., Peterson, B. C., Gerding, D. N. and Cleary, P. P. 1979. Physical characterization of ten $\mathrm{R}$ plasmids obtained from an outbreak of nosocomial Klebsiella pneumoniae infections. Antimicrob. Agents Chemother., 15, 616.

TALANDA-FATH, C. 1980. Characterization of a multiple antibiotic resistance plasmid from Proteus mirabilis. Master's thesis, Stritch School of Medicine, Loyola University of Chicago. 